\title{
The Control of Fatty Acid and Triglyceride Synthesis in Rat Epididymal Adipose Tissue
}

\author{
ROLES OF COENZYME A DERIVATIVES, CITRATE AND L-GLYCEROL 3-PHOSPHATE
}

\author{
By R. M. DENTON AND M. L. HALPERIN* \\ Department of Biochemistry, University of Bristol
}

(Received 2 May 1968)

\begin{abstract}
1. Methods are described for the extraction and assay of acetyl-CoA and of total acid-soluble and total acid-insoluble $\mathrm{CoA}$ derivatives in rat epididymal adipose tissue. 2. The concentration ranges of the CoA derivatives in fat pads incubated in vitro under various conditions were: total acid-soluble CoA, $0 \cdot 20-0.59 \mathrm{~mm}$; total acid-insoluble CoA, 0.08-0.23 mM; acetyl-CoA, 0.03-0.14 mM. 3. An investigation was made of some postulated mechanisms of control of fatty acid and triglyceride synthesis in rat epididymal fat pads incubated in vitro. The concentrations of intermediates of possible regulatory significance were measured at various rates of fatty acid and triglyceride synthesis produced by the addition to the incubation medium (Krebs bicarbonate buffer containing glucose) of insulin, adrenaline, albumin, palmitate or acetate. 4. The whole-tissue concentrations of glucose 6-phosphate, L-glycerol 3-phosphate, citrate, acetyl-CoA, total acid-soluble CoA and total acid-insoluble CoA were assayed after 30 or $60 \mathrm{~min}$. incubation. The rates of fatty acid and triglyceride synthesis, calculated from the incorporation of [U-14C]glucose into fatty acids and glyceride glycerol respectively, and the rates of glucose uptake, lactate plus pyruvate output and glycerol output were measured over a $60 \mathrm{~min}$. incubation. 5. The rate of triglyceride synthesis could not be correlated with the concentrations of either L-glycerol 3-phosphate or long-chain fatty acyl-CoA (measured as total acid-insoluble CoA). Factor(s) other than the wholetissue concentrations of these recognized precursors appear to be involved in the determination of the rate of triglyceride synthesis. 6. No relationship was found between the rate of fatty acid synthesis and the whole-tissue concentrations of the intermediates, citrate or acetyl-CoA, or with the two proposed effectors of acetyl-CoA carboxylase, citrate (as activator) or long-chain fatty acyl-OoA (as inhibitor). The control of fatty acid synthesis appears to reside in additional or alternative factors.
\end{abstract}

Measurements of rates of flow through metabolic pathways coupled with assay of steady-state concentrations of intermediates have yielded valuable information about the enzymes of regulatory significance in a number of tissues (e.g. muscle, brain and liver). Methods for the calculation of rates of flow of carbon atoms through the pathways of glucose and lipid metabolism in rat epididymal adipose tissue have been described (Flatt \& Ball, 1964; Landau, Bartsch, Katz \& Wood, 1964; Denton \& Randle, 1967). Methods are also available for the extraction and measurement of steady-state concentrations of some important metabolites in this tissue (Denton, Yorke \& Randle, 1966). In this paper these methods have been extended to

* Present address: University of Toronto, School of Medicine, Department of Medicine, Toronto, Ont., Canada. include the extraction and measurement of CoA $†$ derivatives in adipose tissue.

L-Glycerol 3-phosphate and long-chain fatty acyl-CoA are the recognized precursors of glyceride glycerol and glyceride fatty acids respectively (Weiss \& Kennedy, 1956 ; Smith, Weiss \& Kennedy, 1957; Steinberg, Vaughan \& Margolis, 1961), and the suggestion has been made by a number of workers that the concentrations of either or both of these substrates in adipose tissue may be critical in determining the rate of triglyceride synthesis. Factors proposed to control the rates of fatty acid

† Abbreviations: to ensure clear distinction between thiol forms of coenzyme $A$ and its derivatives, the following are used: CoASH, thiol form of coenzyme A; acyl-Cis A, thiol esters of coenzyme $A$; CoA, coenzyme $A$ and itis derivatives in general. 
synthesis in adipose tissue are the concentrations of substrates (acetyl-CoA and citrate) and of possible effectors of acetyl-CoA carboxylase (EC 6.4.1.2), e.g. long-chain fatty acyl-CoA as an inhibitor (Bortz \& Lynen, 1963) and citrate as an activator (Martin \& Vagelos, 1962; Vagelos, Alberts \& Martin, 1963). However, citrate is an inhibitor of adipose tissue phosphofructokinase (EC 2.7.1.11), and this could be in conflict with a possible role as an activator of fatty acid synthesis from glucose (Denton \& Randle, 1966).

The object of the present study was to evaluate the significance of these suggested mediators in the acute control of fatty acid synthesis and esterification. Insulin, adrenaline, albumin, palmitate and acetate were added to the incubation media to alter the rates of triglyceride and fatty acid synthesis in vitro. The changes in these rates were correlated with the changes in substrate and possible effector concentrations.

\section{EXPERIMENTAL}

\section{Materials}

Rats. Epididymal fat pads were obtained from male Wistar rats (150-250g.) fed on a stock laboratory diet $41 B$ (Short \& Parkes, 1949). In all experiments the animals were allowed free access to food before the time of killing (approx. 10 a.m.). In any one experiment the rats were of the same age and similar weight ( $\pm 15 \mathrm{~g}$.).

Chemicals. Enzymes, glycolytic intermediates, adenine nucleotides, coenzymes and triethanolamine hydrochloride were obtained from Boehringer Corp. (London) Ltd., London, W. 5, 2-mercaptoethanol and DL-carnitine were from Koch-Light Laboratories Ltd., Colnbrook, Bucks., dithiothreitol (Cleland's reagent) was from Calbiochem, Los Angeles, Calif., U.S.A., and adrenaline was from Hopkin and Williams Ltd., Chadwell Heath, Essex. Crystalline insulin was given by Boots Pure Drug Co. Ltd., Nottingham, and was dissolved in $3.3 \mathrm{~mm}$.HCl to yield a stock solution of 20 units $/ \mathrm{ml}$., which was diluted to the required concentration with the incubation medium. Bovine plasma albumin (fraction V), from the Armour Pharmaceutical Co. Ltd., Eastbourne, Sussex, was treated with charcoal to remove fatty acids (Chen, 1966) and passed through a cellulose column (Vallance-Owen, Dennes \& Campbell, 1958) to remove insulin. The resulting preparation was free of both insulin (tested by radioimmunoassay, kindly performed by Dr W. C. Walker and Dr P. Keane, Department of Chemical Pathology, University of Bristol), and citrate (tested by enzymic assay; Moellering \& Gruber, 1966), and contained less than $1.5 \mu$ equiv. of fatty acids/g. (assayed by the method of Duncombe, 1963).

Acetyl-CoA was synthesized by the method of Simon \& Shemin (1953) and palmitoyl-CoA by the method of Seubert (1960). [U-14 C]Glucose (4 mc/m-mole) and sodium [U.14 C]acetate $(20 \mathrm{mc} / \mathrm{m}$-mole) were obtained from The Radiochemical Centre, Amersham, Bucks. The radiochemical purity was greater than $99 \%$.

2-Oxoglutarate dehydrogenase (EC 1.2.4.2) was purified from pig heart by the method of Sanadi, Littlefield \& Bock (1952).
Diethyl ether (analytical reagent grade) was freed of peroxide immediately before use by passage through a column of alumina (M. Woelm, Eschwege, Germany).

Media. Fat pads were incubated in a Krebs bicarbonatebuffered medium (Krebs \& Henseleit, 1932) gassed with $\mathrm{O}_{2}+\mathrm{CO}_{2}(95: 5)$. The concentrations of the various additions are given in the text or Tables. Media that contained albumin were dialysed against $20 \mathrm{vol}$. of the medium buffer solution for $18 \mathrm{hr}$. at $4^{\circ}$; Visking seamless cellulose tubing, treated to remove plasticizing substances as described by Garland, Newsholme \& Randle (1964), was used. Palmitate was added as the potassium salt, dissolved in a small volume of $50 \%(\mathrm{v} / \mathrm{v})$ ethanol, before dialysis.

\section{Procedure}

Incubation of epididymal fat pads. Epididymal fat pads were prepared, and incubated after a $30 \mathrm{~min}$. preincubation period, as described by Denton \& Randle (1967) except that the total incubation volume was $10 \mathrm{ml}$. and each flask contained four to six fat pads. The initial and final $\mathrm{pH}$ was $7 \cdot 4$.

Extraction and analysis of fat pads. At the end of the incubation, the pads were blotted lightly and frozen in liquid $\mathrm{N}_{2}$. This method of freezing was found to give similar results to those obtained with clamps previously cooled in liquid $\mathrm{N}_{2}$ (Wollenberger, Ristau \& Schoffa, 1960). The pads were ground under liquid $\mathrm{N}_{2}$ and weighed. A portion $(0.5 \mathrm{~g}$.) of the frozen powder was extracted in $25 \mathrm{ml}$. of chloroform-methanol $(2: 1, v / v)$ and assayed for ${ }^{14} \mathrm{C}$ in glyceride glycerol and fatty acids as described by Denton \& Randle (1967). The remainder of the frozen powder was extracted with ice-cold $5 \%(\mathrm{w} / \mathrm{v}) \mathrm{HClO}_{4}(5 \mathrm{ml}$.) and peroxidefree diethyl ether $(10 \mathrm{ml}$.) in a motor-driven all-glass tissue grinder (obtained from Kontes Glass Co., Vineland, N.J., U.S.A., and modified for use in a bench centrifuge). After centrifugation, the ether phase was removed by aspiration. Two additional ether extractions were required to remove most of the lipid. The ether contained in the aqueous phase was removed under reduced pressure. The precipitate was washed with $2 \mathrm{ml}$. of $5 \%$ (w/v) $\mathrm{HClO}_{4}$, and the aqueous phases were combined.

For the assay of total acid-soluble CoA, $2 \mathrm{ml}$. of the aqueous extract was adjusted to $\mathrm{pH} \mathrm{6.5}$ on a glass electrode with $\mathrm{KOH}$ in the presence of $5 \mathrm{~mm}$-dithiothreitol and $50 \mathrm{~mm}$ triethanolamine hydrochloride. For the assay of acetyl-CoA and other acid-soluble intermediates, the remainder of the aqueous phase was adjusted to $\mathrm{pH} 6.5$ on a glass electrode with $\mathrm{KOH}$ in the presence of triethanolamine hydrochloride $(50 \mathrm{~mm})$. All the extracts were then freeze-dried.

The precipitate of the $\mathrm{HClO}_{4}$ extract was analysed for acid-insoluble $\mathrm{CoA}$ as follows. A suspension in $2 \mathrm{ml}$. of $50 \mathrm{~mm}$-potassium phosphate buffer, $\mathrm{pH} 7 \cdot 0$, containing $25 \mathrm{~mm}-2$-mercaptoethanol was brought to $\mathrm{pH} 13$ by adding $\mathrm{KOH}(10 \mathrm{M})$, and incubated for $10 \mathrm{~min}$. at $45^{\circ}$. The solution was then acidified ( $\mathrm{pH} 1.0)$ with $70 \%$ (w/v) $\mathrm{HClO}_{4}$ and kept on ice for $10 \mathrm{~min}$. before centrifugation. A portion of the supernatant was adjusted with $\mathrm{KOH}$ to $\mathrm{pH} 7$ and assayed promptly for CoASH as described in the Methods section.

Analysis of incubation media. Glucose uptake and pyruvate, lactate and glycerol outputs were measured as described by Denton \& Randle (1967). Fatty acids in the medium were extracted by the modified Dole procedure 
(Dole \& Meinertz, 1960; Trout, Estes \& Friedberg, 1960) and radioactivity was then determined in this fraction.

\section{Methods}

Glucose, lactate, pyruvate and glycerol. Spectrophotometric assays based on the following enzymic methods were used: glucose, Slein (1963); lactate, Hohorst (1963c); pyruvate, Bücher, Czok, Lamprecht \& Latzko (1963); glycerol, Garland \& Randle (1962).

Intermediates. L-Glycerol 3-phosphate and glucose 6-phosphate were assayed fluorimetrically by techniques based on methods of Hohorst $(1963 a, b)$. Citrate was assayed fluorimetrically by the method of Moellering \& Gruber (1966). Carnitine was assayed spectrophotometrically by the method of Marquis \& Fritz (1964). Acetyl-CoA was assayed spectrophotometrically in cuvettes $(4 \mathrm{~cm}$. light-path) in a total volume of $1.55 \mathrm{ml}$. by the method of Chase (1967), or fluorimetrically by the method of Wieland \& Weiss (1963) with the correction suggested by Pearson (1965). CoASH was measured fluorimetrically with 2-oxoglutarate dehydrogenase (EC 1.2.4.2) as described by Garland, Shepherd \& Yates (1965). Free fatty acids in incubation media extracted by the modified Dole procedure were assayed by the method of Duncombe (1963). In tissue, the same extraction procedure was used but, in addition, phospholipids were removed by treating the tissue lipid in chloroform with activated silicic acid (Carlson, 1963).

Radioactive assay. ${ }^{14} \mathrm{C}$-labelled compounds were assayed in a Nuclear-Chicago liquid scintillation system (model Mark 1). For aqueous solutions the scintillator was 1,4-dioxan containing naphthalene, 2,5-diphenyloxazole and 1,4-bis-(5-phenyloxazol-2-yl)benzene (Butler, 1961). For solutions in organic solvents ( $n$-heptane), the scintillator was toluene containing 2,5-phenyloxazole and 1,4-bis(5-phenyloxazol-2-yl)benzene (Synder, 1961). Quenching corrections were calculated from the channels-ratio method by using an external standard of ${ }^{133} \mathrm{Ba}$.

Recoveries of intermediates. All acid-soluble intermediates measured, except CoASH, were stable to freeze-drying under the conditions employed. When CoASH was added to 5 mM-dithiothreitol and then freeze-dried, none was lost. However, acetyl-CoA was quantitatively converted into acetate and CoASH under these conditions. Further, alkaline hydrolysis of tissue extracts that were then freezedried in the presence of $5 \mathrm{~mm}$-dithiothreitol did not result in the formation of any additional CoASH. Therefore it was assumed that the total acid-soluble CoA, measured as CoASH after freeze-drying with Cleland's reagent, represented CoASH plus alkali-labile CoA derivatives such as acetyl-CoA.

Recovery experiments were performed by adding the various intermediates, in quantities approximately equal to the amounts in the tissue, at the time of extraction of the pooled fat pads with $\mathrm{HClO}_{4}$-diethyl ether. Acetyl-CoA recovery was $86 \pm 3 \%$ (mean \pm s.t.m. of five observations); CoASH recovery was $94 \pm 3 \%$ (four observations) and carnitine recovery was $\overline{\mathbf{9 3}} \pm \mathbf{7} \%$ (seven observations). Recovery of palmitoyl-CoA both in the presence and in the absence of albumin was $90 \pm 4.5 \%$ (five observations).

Calculation and expression of results. Flows of carbon atoms (glucose uptake, outputs of pyruvate, lactate and g]ycerol and flow of glucose carbon atoms to glyceride glycerol, tissue fatty acids and medium fatty acids) were calculated as $\mu$ g.atoms of carbon/g. wet wt. of fat pad/hr., as described by Denton \& Randle (1967), from the incor. poration of ${ }^{14} \mathrm{C}$ and the specific radioactivity of the medium [U.14C]glucose. In the experiments with acetate (Table 6) the specific radioactivities, expressed as $\mu \mathrm{c} / \mu \mathrm{g}$.atoms of carbon, of the medium glucose and acetate were the same. Concentrations of metabolites were calculated as $\mathrm{m} \mu \mathrm{moles} / \mathrm{g}$. wet wt. of fat pad.

\section{RESULTS}

Effects of time on the concentration of intermediates in rat epididymal fat pads in vitro. To demonstrate that the intermediates did not vary significantly in concentration during the experimental period during which flow rates were determined, their concentrations were measured in two separate experimental conditions, after 30 and after $60 \mathrm{~min}$. of incubation (Table 1). The first set of experiments $(A$ and $B$ ) demonstrated the effects of adrenaline in the absence of albumin, and the second set $(C$ and $D$ ) showed the effects of adrenaline in the presence of albumin. Since groups of paired fat pads were used at each time, we expressed the concentrations of intermediates in tissues incubated with adrenaline as percentages of those found in tissues incubated in its absence to minimize variations between groups of rats that may be due to age, weight, nutritional status or other factors. The actual values at $60 \mathrm{~min}$. are shown in Table 4 (Expts. 2 and 3). Any significant change noted at $60 \mathrm{~min}$. was also apparent at $30 \mathrm{~min}$. and, further, the magnitude of the changes was similar at the two times.

On the basis of these studies, adipose tissue appears to show a steady state of metabolite concentration during the experimental period of 30-60 min. Previous studies (Winegrad \& Renold, 1958; Ball, Martin \& Cooper, 1959; Denton et al. 1966) indicated that the rates of glucose uptake, of lactate, pyruvate and glycerol outputs, of conversion of [U-14C]glucose into carbon dioxide and lipid, and of net gas exchange, were all constant during this period of incubation.

Effects of albumin on intermediate concentrations in rat epididymal fat pad in vitro. These results are reported in Table 2 . In the absence of adrenaline, albumin did not produce any changes in the concentrations of $\mathrm{CoA}$ derivatives, glucose 6-phosphate, L-glycerol 3-phosphate or citrate. However, when adrenaline was present, albumin increased the concentrations of total acid-insoluble CoA (1·3-fold) and citrate (1-8-fold) and decreased the concentrations of acetyl-CoA $(0 \cdot 5$-fold $)$ and L-glycerol 3-phosphate $(0 \cdot 6$-fold $)$.

The rates of the uptake of glucose, the outputs of lactate, pyruvate and glycerol and the flow of glucose carbon atoms into glyceride glycerol and fatty acids were also measured in these experiments. 
Table 1. Effects of incubation time on the changes in concentration of CoA derivatives, glucose 6-phosphate, L-glycerol 3-phosphate and citrate produced by adrenaline in the absence or presence of albumin

Fat pads were preincubated for $30 \mathrm{~min}$. in medium containing glucose $(3 \mathrm{mg} . / \mathrm{ml}$.) and then incubated for $30 \mathrm{~min}$. or $60 \mathrm{~min}$. in fresh medium containing glucose $(3 \mathrm{mg} . / \mathrm{ml}$.$) and, where added, bovine plasma albumin$ $(20 \mathrm{mg} . / \mathrm{ml}$.) and adrenaline $(5 \mu \mathrm{g} . / \mathrm{ml}$.$) . Results are expressed as the concentration in tissues incubated with$ adrenaline as a percentage of the concentration in control tissues incubated in the absence of adrenaline. Mean values \pm S.E.M. are given for paired groups of four to six fat pads (numbers of pairs of groups are shown in parentheses), except where analyses were made on single pools of 16 fat pads.

\begin{tabular}{|c|c|c|c|c|c|c|c|c|c|}
\hline \multirow{2}{*}{\multicolumn{2}{|c|}{$\begin{array}{c}\text { Time of } \\
\text { incubation } \\
\text { Expt. (min.) }\end{array}$}} & \multicolumn{2}{|c|}{$\begin{array}{c}\text { Additions to } \\
\text { incubation media }\end{array}$} & \multicolumn{6}{|c|}{ Experimental concn. ( $\%$ of control concn.) } \\
\hline & & Control & $\overbrace{\begin{array}{c}\text { Experi- } \\
\text { mental }\end{array}}$ & $\begin{array}{c}\text { Acid- } \\
\text { insoluble } \\
\text { CoA }\end{array}$ & $\begin{array}{l}\text { Acid- } \\
\text { soluble } \\
\text { CoA }\end{array}$ & Acetyl-CoA & $\begin{array}{c}\text { Glucose } \\
\text { 6-phosphate }\end{array}$ & $\begin{array}{l}\text { L-Glycerol } \\
\text { 3-phosphate }\end{array}$ & Citrate \\
\hline $\begin{array}{l}A \\
B\end{array}$ & $\begin{array}{l}30 \\
60 \\
P \text { valu }\end{array}$ & $\begin{array}{l}\text { None } \\
\text { None } \\
\text { lues }(A \text { ver }\end{array}$ & $\begin{array}{l}\text { Adrenaline } \\
\text { Adrenaline } \\
\text { arsus } B \text { ) }\end{array}$ & $\begin{array}{c}73 \pm 6 \quad(8) \\
82 \pm 12(4) \\
>0.05\end{array}$ & $\begin{array}{c}127 \pm 10(8) \\
96 \pm 11(4) \\
>0.05\end{array}$ & $\begin{array}{l}322 \pm 47(8) \\
279 \\
\quad>0.05\end{array}$ & $\begin{array}{r}75 \pm 10(8) \\
124 \pm 24(4) \\
>0.05\end{array}$ & $\begin{array}{c}122 \pm 18(8) \\
135 \pm 13(4) \\
>0.05\end{array}$ & $\begin{array}{c}123 \pm 16(8) \\
135 \pm 15(4) \\
>0.05\end{array}$ \\
\hline$C$ & 30 & Albumin & $\begin{array}{l}\text { Albumin }+ \\
\text { adrenaline }\end{array}$ & $109 \pm 4$ & $88 \pm 16(4)$ & $172 \pm 72(4)$ & $128 \pm 4 \cdot 4(4)$ & $68 \pm 4$ & $225 \pm 21(4)$ \\
\hline$D$ & $\begin{array}{l}60 \\
P \text { valu }\end{array}$ & $\begin{array}{l}\text { Albumin } \\
\text { ues }(C \text { ver }\end{array}$ & $\begin{array}{l}\text { Albumin }+ \\
\text { adrenaline } \\
\text { rsus } D \text { ) }\end{array}$ & $\begin{array}{c}110 \pm 4 \quad(4) \\
>0.05\end{array}$ & $\begin{array}{c}132 \pm 21(4) \\
>0.05\end{array}$ & $\begin{array}{l}112 \\
\quad>0.05\end{array}$ & $\begin{array}{c}144 \pm 15(4) \\
>0.05\end{array}$ & $\begin{array}{c}61 \pm 6 \quad(4) \\
>0.05\end{array}$ & $\begin{array}{c}236 \pm 26(4) \\
>0.05\end{array}$ \\
\hline
\end{tabular}

Table 2. Effects of albumin on the steady-state concentrations of CoA derivatives, glucose 6-phosphate, L-glycerol 3-phosphate and citrate

Incubation conditions were as in Table 1. Results are expressed as the concentration in tissues incubated with albumin as a percentage of the concentration in control tissues incubated without albumin. Mean values \pm s.E.M. are given for four paired groups of four to six pads except where analyses were made on single pools of 16 pads. *** $P<0.01$, ** $P<0.02$; for other differences $P>0.05$ (versus $100 \%$ )

\begin{tabular}{|c|c|c|c|c|c|c|c|c|}
\hline \multirow{3}{*}{$\begin{array}{c}\text { Incubation } \\
\text { time } \\
\text { (min.) }\end{array}$} & \multirow{2}{*}{\multicolumn{2}{|c|}{$\begin{array}{c}\text { Additions to } \\
\text { incubation media }\end{array}$}} & \multicolumn{6}{|c|}{ Experimental concn. ( $\%$ of control concn.) } \\
\hline & & & Acid- & Acid- & & Glucose & L-Glycerol & \\
\hline & Control & Experimental & insoluble $\mathrm{CoA}$ & soluble $\mathrm{CoA}$ & Acetyl-CoA & 6-phosphate & 3-phosphate & Citrate \\
\hline $\begin{array}{l}30 \\
60\end{array}$ & $\begin{array}{l}\text { None } \\
\text { Adrenaline }\end{array}$ & $\begin{array}{l}\text { Albumin } \\
\text { Adrenaline + } \\
\text { albumin }\end{array}$ & $\begin{array}{l}107 \pm 4 \cdot 8 \\
128 \pm 5 \cdot 2^{* *}\end{array}$ & $\begin{array}{r}99 \pm 12 \\
125 \pm 16\end{array}$ & $\begin{array}{c}114 \pm 10 \\
48 \cdot 5\end{array}$ & $\begin{array}{l}100 \pm 22 \\
144 \pm 15\end{array}$ & $\begin{array}{l}102 \pm 8 \\
61 \pm 6 \cdot 7 * * *\end{array}$ & $\begin{array}{c}99 \pm 8 \\
187 \pm 3^{* * *}\end{array}$ \\
\hline
\end{tabular}

In the absence of adrenaline the only change noted was a small but significant decrease in pyruvate output $(0 \cdot 8$-fold). In the presence of adrenaline, pyruvate output was increased (1.6-fold), as was the flow of glucose carbon atoms into fatty acids (2-3-fold).

Effects of insulin, adrenaline and palmitate on flow rates and intermediate concentrations in rat epididymal fat pad in vitro. Results are recorded in Tables 3 and 4. In Table 3, the values for uptake of glucose, outputs of lactate plus pyruvate and of glycerol and the rates of incorporation of glucose carbon atoms into glyceride glycerol and fatty acids (tissue plus medium) are given under the various experimental conditions. The values of glucose uptake in the absence of insulin or adrenaline may only be approximate because of the errors inherent in measuring very small glucose uptakes. When albumin was present, up to $18 \%$ of the radioactivity in fatty acids was present in the incubation medium; in its absence, the corresponding value was less than $1 \%$.

In Table 4, the concentrations of total acidinsoluble CoA, total acid-soluble CoA and acetylCoA, together with the concentrations of carnitine, glucose 6-phosphate, L-glycerol 3-phosphate and citrate, are shown.

Expt. 1.Insulin increased glucose uptake (sixfold), and the output of lactate plus pyruvate (1-6-fold) but not that of glycerol. Glucose incorporation into glyceride glycerol $(2 \cdot 2$-fold $)$ and fatty acids (6.5-fold) was enhanced. The concentration of acid-insoluble CoA was decreased ( $0 \cdot 5$-fold), whereas that of acid-soluble CoA was increased (1-6-fold), as was that of acetyl-CoA (1-3-fold). In a separate experiment, carnitine concentration was increased 
Vol. 110

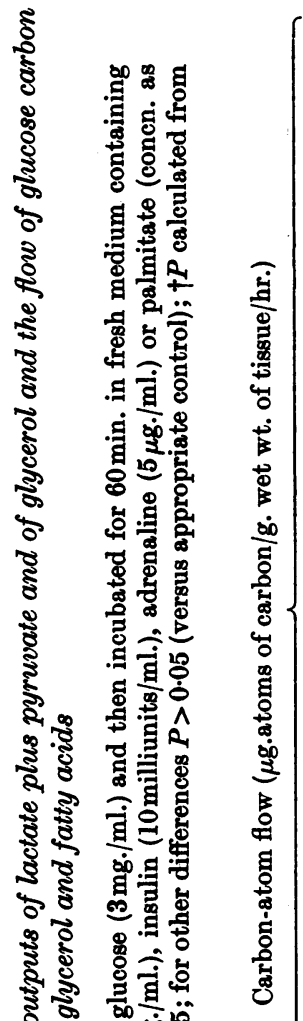

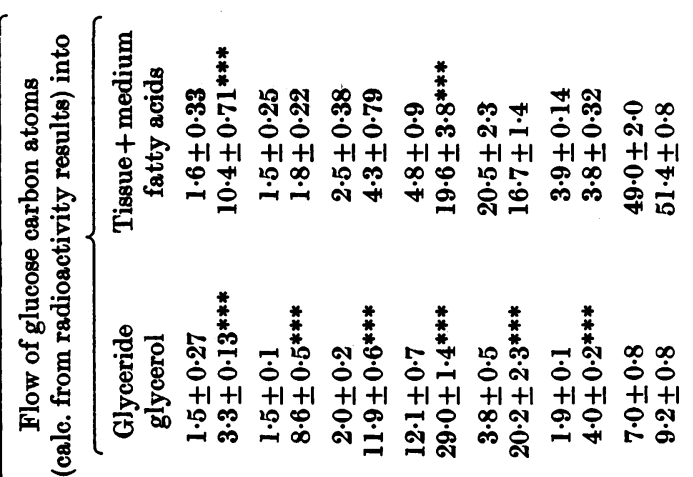

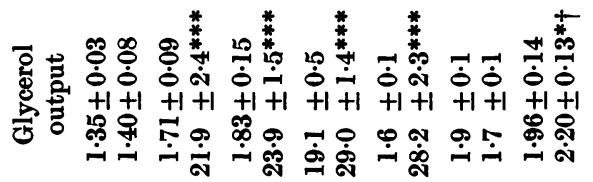

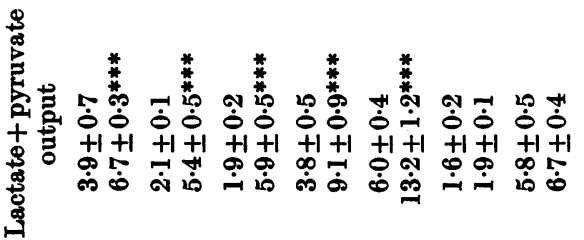

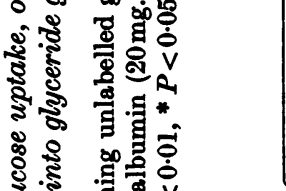

कू कै

है छิ

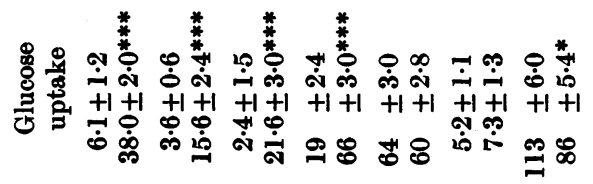

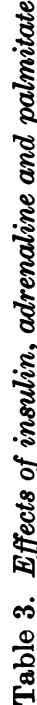

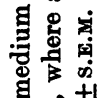

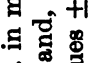

需

酸

总家

密

宊

空的

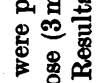

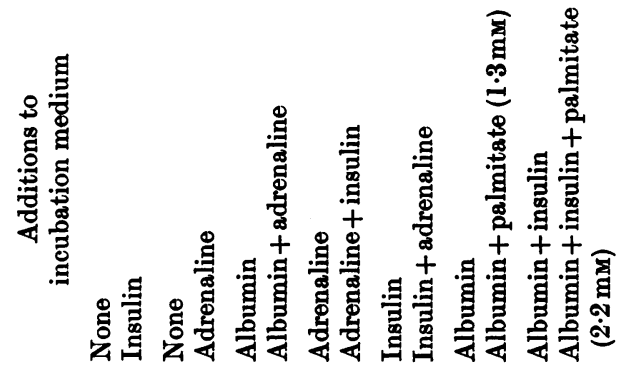

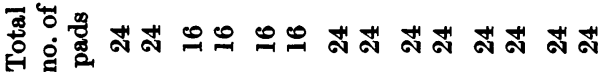

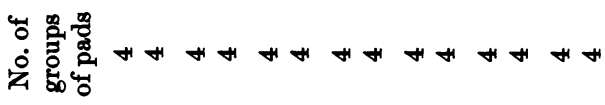

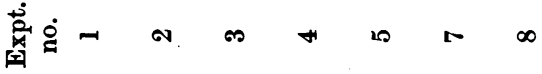




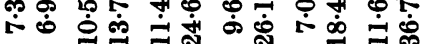

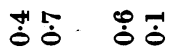

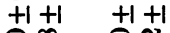

这変这

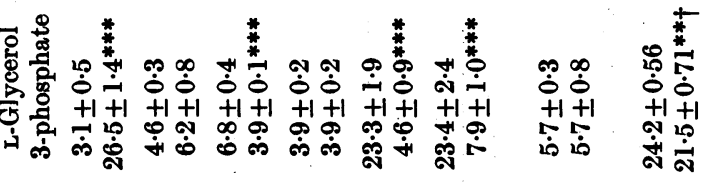

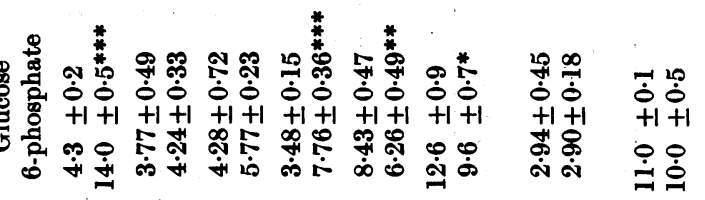

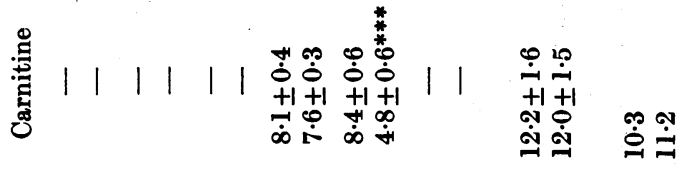

ర்ุ

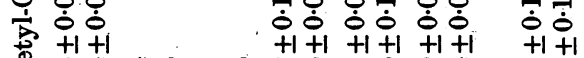

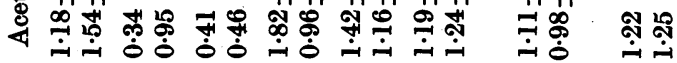

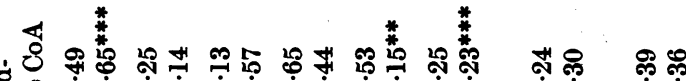

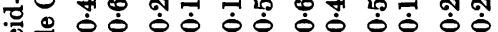

$403+1+1+1+1+1+1+1+1+1+1+1$ i $+1+1$

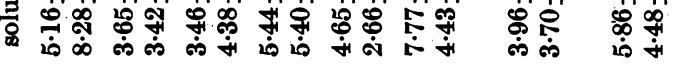

इ क्षे

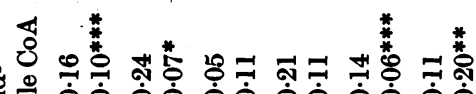

递

$403+1+1+1+1+1+1+1+1+1+1+1+1$ .

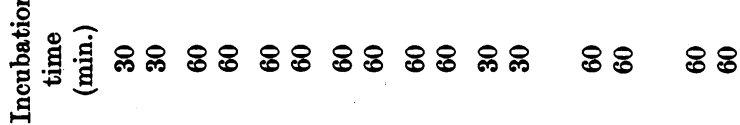

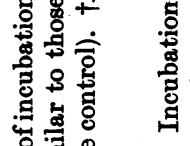

.

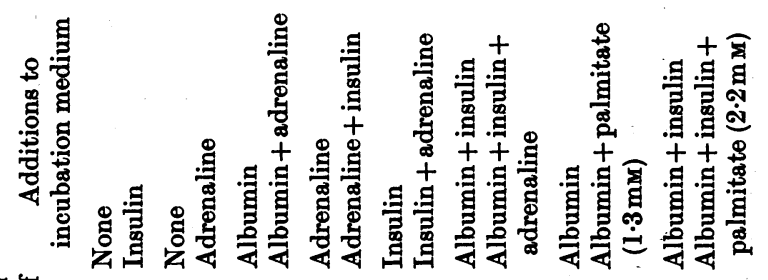

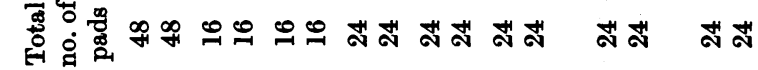

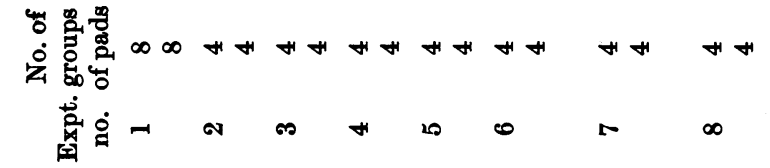


$[1 \cdot 24( \pm 0 \cdot 06)$-fold] (mean \pm S.E.M. of four paired observations). As previously reported, insulin increased the concentration of glucose 6-phosphate (3.3-fold) and L-glycerol 3-phosphate (8.5-fold), without any alteration in the concentration of citrate (Denton et al. 1966).

Expts. 2 and 3. Adrenaline increased glucose uptake (fourfold) and increased the outputs of lactate plus pyruvate $(2 \cdot 5$-fold $)$ and of glycerol (13-fold). Glucose incorporation into glyceride glycerol was increased sixfold, but there was no significant increase in the flow to fatty acids. All these changes in flow rates were similar in the presence and in the absence of albumin. There was no change in the concentrations of acid-soluble CoA and glucose 6-phosphate in either case. Only in the absence of albumin was there a significant change in acid-insoluble CoA $(0 \cdot 8$-fold $)$ and in acetyl-CoA (2.8-fold). L-Glycerol 3-phosphate was significantly decreased $(0 \cdot 6$-fold $)$ only in the presence of albumin. Citrate was increased in the absence (1.3-fold) and in the presence (2.4-fold) of albumin.

Expt. 4. Insulin in the presence of adrenaline increased glucose uptake (3.5-fold) and outputs of lactate plus pyruvate $(2 \cdot 5$-fold) and of glycerol $(1.5-$ fold). Glucose incorporation into glyceride glycerol was enhanced $(2 \cdot 5$-fold), as was that into fatty acids (fourfold). The concentration of acetyl-CoA was significantly decreased $(0 \cdot 5$-fold $)$, and those of glucose 6-phosphate and citrate were increased (2.2-fold and 2.5-fold respectively). No significant change was seen in the concentrations of the other intermediates measured. Tissue free fatty acid concentrations were also measured (the values are not included in the Tables); insulin caused a decrease in tissue free fatty acid concentration, from $18.0 \pm 1.9$ to $8.0 \pm 1.5 \mu$ equiv./g. of wet tissue (mean \pm S.E.M. for four observations in both cases).

The augmented glycerol output produced by insulin in the presence of adrenaline is in agreement with the findings of Jungas \& Ball (1963).

Expts. 5 and 6. Adrenaline in the presence of insulin did not alter the rate of glucose uptake, but increased the outputs of lactate plus pyruvate (2-2-fold) and of glycerol (13-fold). Glucose incorporation into glyceride glycerol was increased fivefold but there was no significant change in fatty acid synthesis. In the presence of albumin and insulin, Denton \& Randle (1967) found that adrenaline produced similar results to these, but fatty acid synthesis was significantly decreased. Adrenaline increased the acid-insoluble CoA concentration ( $1 \cdot 5$-fold), and lowered that of acid-soluble CoA (0.6-fold), without altering the concentration of acetyl-CoA. Carnitine concentration was approximately halved. The concentration of glucose 6-phosphate was decreased somewhat (0.75-fold), and that of L-glycerol 3-phosphate was decreased markedly $(0 \cdot 2$-fold), whereas that of citrate was increased $(2 \cdot 2$-fold $)$. These effects were similar in the absence and in the presence of albumin.

Expts. 7 and 8. In the absence of insulin, palmitate increased the incorporation of glucose carbon atoms into glyceride glycerol twofold but had no effect on any of the other carbon-atom flows measured. In the presence of insulin, a small decrease in glucose uptake (0.75-fold) and a small increase in glycerol output (1.1-fold) were the only changes noted. Palmitate caused no significant change in the concentration of any of the intermediates measured, either in the presence or in the absence of insulin, with the exception of a small decrease in L-glycerol 3-phosphate $(0 \cdot 9$-fold) in the presence of insulin.

In the presence of palmitate in the incubation medium there was an appreciable increase in the transfer or exchange of radioactive fatty acids from the tissue into the medium. These results are reported in Table 5.

\section{Table 5. Effect of palmitate in the absence and in the presence of insulin on the flow of glucose carbon atoms into the fatty acids of the tissue and of the medium}

For further details see Table 3 (Expts. nos. 7 and 8 ), from which these values were obtained. $* * * P<0.01$; for other differences $P>0.05$ (versus appropriate control).

Carbon-atom flow ( $\mu$ g.atoms of carbon/g. wet wt. of tissue/hr.) (calc. from radioactivity results) into

\begin{tabular}{cl}
$\begin{array}{c}\text { Expt. } \\
\text { no. }\end{array}$ & \multicolumn{1}{c}{$\begin{array}{c}\text { Additions to incubation } \\
\text { medium }\end{array}$} \\
7 & $\begin{array}{l}\text { Albumin } \\
\text { Albumin + palmitate }(1 \cdot 3 \mathrm{~mm})\end{array}$ \\
8 & $\begin{array}{l}\text { Albumin + insulin } \\
\text { Albumin + insulin + palmitate } \\
(2 \cdot 2 \mathrm{~mm})\end{array}$
\end{tabular}

\begin{tabular}{ccc}
\hline $\begin{array}{c}\text { Tissue } \\
\text { fatty acids }\end{array}$ & $\begin{array}{c}\text { Medium } \\
\text { fatty acids }\end{array}$ & $\begin{array}{c}\text { Tissue }+ \text { medium } \\
\text { fatty acids }\end{array}$ \\
$3.84 \pm 0 \cdot 13$ & $0 \cdot 04 \pm 0.01$ & $3 \cdot 85 \pm 0 \cdot 14$ \\
$3.51 \pm 0.33$ & $0 \cdot 25 \pm 0.02 * * *$ & $3 \cdot 76 \pm 0.32$ \\
$48.3 \pm 1 \cdot 8$ & $0 \cdot 71 \pm 0.21$ & $49 \cdot 1 \pm 2 \cdot 0$ \\
$49.6 \pm 0.7$ & $1 \cdot 83 \pm 0.05 * * *$ & $51 \cdot 8 \pm 0.8$
\end{tabular}

Bioch. 1968, 110 
Table 6. Effect of acetate in the presence of insulin on carbon-atom flows and concentrations of intermediates

Fat pads were preincubated for $30 \mathrm{~min}$. in medium containing unlabelled glucose $(3 \mathrm{mg} . / \mathrm{ml}$. $)$ and then incubated for $60 \mathrm{~min}$. in fresh medium containing [U.14C]glucose $(3 \mathrm{mg} . / \mathrm{ml}$. and $0.02 \mu \mathrm{c} / \mathrm{g}$. atom of carbon) and insulin (10 milliunits $/ \mathrm{ml}$.) and, where added, sodium [U.14C] acetate (15 mM and $0.02 \mu \mathrm{c} / \mathrm{g}$.atom of carbon). Results are given as means \pm s.E.M. for four groups of six fat pads. ${ }^{* * *} P<0.01,{ }^{* *} P<0.02, * P<0.05$; for other differences $P>0.05$ (versus control); all $P$ values were calculated from paired differences.

Carbon-atom flow ( $\mu$ g.atoms of carbon/g. wet wt. of tissue/hr.)

$\overbrace{\begin{array}{l}\text { Flow of glucose + acetate carbon } \\ \text { atoms }\end{array}}^{\text {calc from radioactivity }}$
atoms (calc. from radioactivity results) into

\begin{tabular}{|c|c|c|c|c|c|c|}
\hline $\begin{array}{c}\text { Additions to } \\
\text { incubation medium }\end{array}$ & $\begin{array}{l}\text { Glucose } \\
\text { uptake }\end{array}$ & $\begin{array}{l}\text { Lactate } \\
\text { output }\end{array}$ & $\begin{array}{l}\text { Pyruvate } \\
\text { output }\end{array}$ & $\begin{array}{l}\text { Glycerol } \\
\text { output }\end{array}$ & $\begin{array}{l}\text { Glyceride } \\
\text { glycerol }\end{array}$ & $\begin{array}{c}\text { Tissue }+ \text { medium } \\
\text { fatty acids }\end{array}$ \\
\hline $\begin{array}{l}\text { Insulin } \\
\text { Insulin + acetate }\end{array}$ & $\begin{array}{l}32 \pm 2 \cdot 0 \\
47 \pm 5 \cdot 2 * *\end{array}$ & $\begin{array}{l}5.9 \pm 0.6 \\
4.5 \pm 0.5\end{array}$ & $\begin{array}{l}0.63 \pm 0.08 \\
0.77 \pm 0.11\end{array}$ & $\begin{array}{l}1 \cdot 76 \pm 0 \cdot 13 \\
1 \cdot 47 \pm 0.09\end{array}$ & $\begin{array}{l}3 \cdot 27 \pm 0 \cdot 25 \\
3 \cdot 54 \pm 0 \cdot 33^{*}\end{array}$ & $\begin{array}{c}12 \cdot 5 \pm 3 \cdot 4 \\
17 \cdot 1 \pm 4 \cdot 5^{* * *}\end{array}$ \\
\hline
\end{tabular}

Concn. (m $\mu$ moles/g. wet wt. of tissue)

$\begin{array}{ccccccc}\text { Acid- } & \text { Acid- } & & & \text { Glucose } & \text { L-Glycerol } \\ \text { insoluble CoA } & \text { soluble CoA } & \text { Acetyl-CoA } & \text { Carnitine } & \text { 6-phosphate } & \text { 3-phosphate } & \text { Citrate } \\ 1 \cdot 11 \pm 0 \cdot 14 & 4 \cdot 48 \pm 0 \cdot 45 & 0 \cdot 65 \pm 0 \cdot 08 & 8 \cdot 29 \pm 0 \cdot 81 & 10 \cdot 1 \pm 0 \cdot 6 & 35 \cdot 8 \pm 2 \cdot 6 & 12 \cdot 4 \pm 0 \cdot 4 \\ 1 \cdot 13 \pm 0 \cdot 21 & 4 \cdot 27 \pm 1 \cdot 05 & 1 \cdot 98 \pm 0 \cdot 20^{* * *} & 4 \cdot 84 \pm 0 \cdot 34^{* * *} & 9 \cdot 2 \pm 0 \cdot 5 & 19 \cdot 2 \pm 2 \cdot 6 * * * & 13 \cdot 4 \pm 1 \cdot 0\end{array}$

Effects of acetate on the concentration of intermediates and flow rates in rat epididymal fat pad in vitro. Table 6 shows the effect of acetate in the presence of insulin on the concentrations of intermediates and flow rates. In the presence of acetate, increases in both the rate of glucose uptake (1.4-fold) and the incorporation of carbon atoms into fatty acids (1.4-fold) occurred. There was also a very small increase of incorporation into glyceride glycerol (1·1-fold), but no significant change in other flow rates. These results were similar to those reported by Flatt \& Ball (1966). The concentration of acetyl-CoA was increased threefold, whereas that of L-glycerol 3-phosphate was decreased $(0 \cdot 5$-fold $)$, as was that of carnitine (0.6-fold). The concentrations of other intermediates did not alter.

\section{DISCUSSION}

Measurement of flow rates. The rate of triglyceride synthesis was calculated from the rate of flow of carbon atoms from [U.14C]glucose into glyceride glycerol. This involved the assumptions that the specific radioactivity of L-glycerol 3-phosphate is similar to that of glucose and that only negligible amounts of radioactivity are incorporated into glycerol formed by lipolysis. These assumptions were verified in this tissue by Denton \& Randle (1967). The rate of fatty acid synthesis was calculated from the rate of flow of carbon atoms from [U-14C]glucose into the fatty acids of the tissue plus the medium. A necessary assumption was that the specific radioactivity of the tissue acetyl-CoA is similar to that of glucose. A possible source of error would arise if the endogenous oxidation of fatty acids in the presence of the high medium glucose concentration $(16.5 \mathrm{~mm})$ was sufficient to lower the specific radioactivity of the acetyl-CoA appreciably. However, the rate of oxidation of [1-14C]palmitate to ${ }^{14} \mathrm{CO}_{2}$ in adipose tissue is very low (Bally, Cahill, Leboeuf \& Renold, 1960).

Assay of concentrations of intermediates. The concentrations of metabolites measured in these experiments were whole-tissue concentrations. The possibility of 'compartmentation', especially of CoASH, acetyl-CoA and citrate, has not been excluded. In attempting to draw conclusions about metabolic control mechanisms, it has been necessary to assume, however, that a change in whole-tissue concentration reflects a change in concentration in the relevant compartment(s).

(a) CoA derivatives. We are not aware of other published reports of the measurement of CoA derivatives in adipose tissue. These intermediates have been measured in other tissues by many investigators. We have used essentially similar methods, modified to permit analyses in adipose tissue.

Acetyl-CoA was present in very low concentrations. However, similar results were obtained by both the analytical methods used. The range of concentrations was $0.34-1.98 \mathrm{~m} \mu \mathrm{moles} / \mathrm{g}$. wet wt. Assuming the intracellular water volume to be 
$1.4 \mathrm{ml} . / 100 \mathrm{~g}$. wet wt. (Denton et al. 1966), the concentrations would range from 0.025 to $0 \cdot 142 \mathrm{~m} \mathrm{M}$. These are similar to those in liver (Tubbs \& Garland, 1964) and in the perfused rat heart (Randle, Denton \& England, 1968).

CoA derivatives that are both acid- and etherinsoluble and alkali-labile may be considered to be predominantly long-chain fatty acyl-CoA (Seubert, 1960; Bortz \& Lynen, 1963; Tubbs \& Garland, 1964). The range of concentrations of long-chain fatty acyl-CoA found in adipose tissue was 1.11$3.25 \mathrm{~m} \mu \mathrm{moles} / \mathrm{g}$. wet wt., corresponding to 0.08 $0.23 \mathrm{~mm}$. This concentration range is similar to that reported for liver (Tubbs \& Garland, 1964) but somewhat higher than that found in the perfused rat heart (Garland \& Randle, 1964).

The total acid-soluble CoA fraction represents free CoASH and soluble acyl derivatives of CoA (acetyl-CoA, malonyl-CoA etc.). The range of concentrations found was $2 \cdot 7-8 \cdot 3 \mathrm{~m} \mu \mathrm{moles} / \mathrm{g}$. wet wt., corresponding to $0 \cdot 20-0.59 \mathrm{~mm}$. These values are again similar to those found in liver, but somewhat greater than those in perfused rat heart (Tubbs \& Garland, 1964; Garland \& Randle, 1964).

Recent work with hamster intestinal homogenates suggests that a protein-bound $\mathrm{CoA}$ derivative may be involved in triglyceride synthesis via the monoglyceride pathway (Rao \& Johnston, 1967). This, or possibly other bound $\mathrm{CoA}$ derivatives, could also be included in either the acid-soluble or acidinsoluble CoA fractions.

(b) Carnitine. Carnitine concentrations in adipose tissue are similar to those reported by Pearson $\&$ Tubbs (1967). The concentration of free carnitine varied only in those experiments in which free CoASH (total acid-soluble CoA minus acetyl-CoA) was found to alter, and the change was of similar magnitude. Acetylcarnitine could not be detected. The amount of total acid-insoluble carnitine could not be determined.

Effects of albumin. Albumin was added to the incubation medium in several experiments to enhance the rate of efflux of free fatty acids from the adipose tissue. It had been treated to remove insulin, citrate and most of the free fatty acids, and had been dialysed against the medium buffer solution to minimize changes in ionic composition that it might bring about by the binding $\mathrm{Ca}^{2+}$ or other ions to protein.

In the absence of adrenaline, albumin had no demonstrable effect on adipose tissue metabolite concentrations or flow rates (Table 2 and Denton et al. 1966). However, in the presence of adrenaline, it increased the concentrations of acid-insoluble $\mathrm{CoA}$ and citrate, decreased the concentrations of L-glycerol 3-phosphate and acetyl-CoA and, possibly, increased the rate of fatty acid synthesis.

In the presence of insulin, adrenaline produced little or no effect on fatty acid synthesis (Table 3 and Flatt \& Ball, 1964), but in the presence of albumin and insulin a very marked inhibition resulted (Cahill, Leboeuf \& Flinn, 1960; Denton \& Randle, 1966).

We are at present unable to offer an explanation for these effects of albumin.

Effects of palmitate. Some evidence has been put forward that the presence of fatty acids in the incubation medium elicits alterations in glucose metabolism in fat pads similar to those induced by adrenaline (Cahill et al. 1960). However, in our experiments, few of the effects of adrenaline on flow rates and intermediate concentrations were mimicked when palmitate was substituted for adrenaline.

There seems little doubt that fatty acids in complexes with albumin are able to diffuse to the cell membrane and enter the cell, since fat pads readily incorporate labelled palmitate into triglyceride (Bally et al. 1960) and, in our experiments, added palmitate promoted increases in the outputs of newly synthesized fatty acids (Table 5). Thus it would appear that the effects of adrenaline on rat epididymal adipose tissue cannot be entirely accounted for by the effects of this hormone on lipolysis. However, it is possible that the intracellular concentration of fatty acids achieved by adding palmitate to the medium may be less than that attained in the presence of adrenaline.

Role of L-glycerol 3-phosphate, citrate and CoA derivatives in controlling triglyceride synthesis and fatty acid synthesis. Insulin increased the rates of both fatty acid synthesis and triglyceride synthesis in adipose tissue, and the tissue concentrations of glucose 6-phosphate, L-glycerol 3-phosphate, acidsoluble CoA and acetyl-CoA were also raised. The concentration of long-chain fatty acyl-CoA was diminished and that of citrate unchanged. One could attribute these effects of insulin to a primary effect on glucose transport (Crofford \& Renold, $1965 a, b)$ leading to a rise in the concentration of L-glycerol 3-phosphate and thereby to an increase in fatty acid esterification. The removal of longchain fatty acyl-CoA by esterification could then result in increased fatty acid synthesis because the suggested feedback inhibition of acetyl-CoA carboxylase would be relieved (see the introduction).

However, investigations of the effects of adrenaline, palmitate and acetate raise doubts about this simple interpretation of the control of fatty acid and triglyceride synthesis.

(a) Triglyceride synthesis. Table 7 correlates the changes in the concentrations of L-glycerol 3-phosphate and long-chain fatty acyl-CoA with the changes in the rates of triglyceride synthesis that have been observed in the present work.

Only in Expt. 1 could an increase in L-glycerol 
Table 7. Relationship between the rate of triglyceride synthesis and the concentrations of L-glycerol 3-phosphate and long-chain fatty acyl-CoA

The rates of triglyceride synthesis were taken from Table 3, except for one value ( $\dagger$ ). The concentrations of L-glycerol 3-phosphate and long-chain fatty acyl-CoA were taken from Table 4. All the results are given as the rate or concentration in experimental tissues expressed as a percentage of that in the control tissue. *** $P<0.01 ; * P<0.05$ when compared with control values (i.e. $100 \%$ ).

\begin{tabular}{|c|c|c|c|c|c|}
\hline \multirow{3}{*}{$\begin{array}{c}\text { Expt. } \\
\text { no. }\end{array}$} & \multirow{2}{*}{\multicolumn{2}{|c|}{ Additions to medium }} & \multirow{3}{*}{$\begin{array}{l}\text { Experimental rate of } \\
\text { triglyceride synthesis } \\
\text { (\% of control rate) }\end{array}$} & \multicolumn{2}{|c|}{ Experimental concn. $(\%$ or control conc } \\
\hline & & & & L-glycerol & Long-chain fatty \\
\hline & Control & Experimental & & 3-phosphate & acyl-CoA \\
\hline 1 & None & Insulin & $222 * * *$ & $855 * * *$ & $52 * * *$ \\
\hline 2 & None & Adrenaline & $572 * * *$ & 135 & $77^{*}$ \\
\hline 3 & Albumin & Albumin + Adrenaline & $587 * * *$ & $57 * * *$ & 110 \\
\hline 4 & Adrenaline & Adrenaline + insulin & $240 * * *$ & 100 & 110 \\
\hline 5 & Insulin & Insulin + adrenaline & $525 * * *$ & $20 * * *$ & $152 * * *$ \\
\hline 6 & $\begin{array}{l}\text { Insulin }+ \\
\text { albumin }\end{array}$ & Insulin + albumin + adrenaline & $468 \dagger^{* * *}$ & $28 * * *$ & $147 * * *$ \\
\hline 7 & Albumin & Albumin + palmitate & $207^{*}$ & 99 & 97 \\
\hline
\end{tabular}

† Denton \& Randle (1967).

3-phosphate concentration account for the increased rate of esterification. In the other experiments the L-glycerol 3-phosphate concentration was either unchanged or decreased, yet in all cases the rate of triglyceride synthesis was increased at least twofold.

Long-chain fatty acyl-CoA concentration was increased in two experiments (Expts. 5 and 6) in which the rate of triglyceride synthesis was increased. In other experiments in which the rate increased, however, the long-chain fatty acylCoA concentration remained unchanged or decreased.

Under two conditions (Expts. 4 and 7) the rate of triglyceride synthesis was more than doubled without changes in the concentration of either L-glycerol 3-phosphate or long-chain fatty acyl-CoA. It could be argued that under these conditions the concentration of fatty acids determined the rate. However, in Expt. 4 the rate increased 2.4-fold whereas the tissue concentration of fatty acids was halved (see the Results section).

In conclusion, it does not appear that the wholetissue concentrations of L-glycerol 3-phosphate, long-chain fatty acyl-CoA or free fatty acids could have been the sole determinants of the rates of triglyceride synthesis under the conditions of the present experiments.

The control of triglyceride synthesis must therefore reside in either a single unrecognized factor or a group of factors, possibly including the substrate concentrations.

(b) Fatty acid synthesis. Table 8 correlates the changes in rate of fatty acid synthesis with the changes in the concentrations of acetyl-CoA, citrate and long-chain fatty acyl-CoA. The order of experiments in the Table has been altered but the original experiment numbers have been retained.

If the rate of fatty acid synthesis were controlled by the concentration of the substrate, acetyl-CoA, one would expect to find increased acetyl-CoA concentrations under conditions where this rate is increased. This was so in Expt. 1 and in the experiment with acetate (Table 6). However, in Expt. 4, the acetyl-CoA concentration was halved but the rate of synthesis was increased fourfold and, in Expt. 2, the acetyl-CoA concentration increased 2.8-fold but there was no significant change in rate of synthesis.

It has been suggested from enzyme-activity studies that acetyl-CoA carboxylase is the ratelimiting step in fatty acid synthesis (Martin \& Vagelos, 1962; Numa, Bortz \& Lynen, 1965). However, there has been no confirmation of this suggestion from studies in intact tissues. There are two known effectors of this enzyme, citrate as an activator and long-chain fatty acyl-CoA as an inhibitor. Certain difficulties arise when one attempts to interpret the physiological role of these effectors. Citrate is an inhibitor of adipose tissue phosphofructokinase and this could conflict with its role as an activator of fatty acid synthesis from glucose. Also Fang \& Lowenstein (1967), in studies with the liver acetyl-CoA carboxylase, demonstrated that citrate activation did not occur in the presence of physiological concentrations of ATP (5-10 mM) and, further, that in the absence of ATP the activation was time-dependent. Fang \& Lowenstein (1967) also pointed out that long-chain fatty 
Table 8. Relationships between the rate of fatty acid synthesis and the concentration of acetyl-CoA, citrate and long-chain acyl-CoA

The rates of fatty acid synthesis were taken from Tables 3 and 6 , except for one value ( $\dagger$ ). The concentrations of acetyl-CoA, citrate and long-chain fatty acyl-CoA were taken from Tables 4 and 6 . All the results are given as the rate or concentration in experimental tissues expressed as a percentage of that in the control tissues. *** $P<0.01$; ** $P<0.02$; * $P<0.05$ when compared with control values (i.e. $100 \%$ ).

\begin{tabular}{|c|c|c|}
\hline \multirow[b]{2}{*}{ Expt. } & \multicolumn{2}{|c|}{ Additions to medium } \\
\hline & Control & Experimental \\
\hline 1 & None & Insulin \\
\hline 4 & Adrenaline & Adrenaline + insulin \\
\hline $\begin{array}{c}\text { Acetate } \\
\text { (Table 6) }\end{array}$ & Insulin & Insulin + acetate \\
\hline 2 & None & Adrenaline \\
\hline 3 & Albumin & Albumin + adrenaline \\
\hline 5 & Insulin & Insulin + adrenaline \\
\hline 6 & $\begin{array}{l}\text { Insulin }+ \\
\text { albumin }\end{array}$ & $\begin{array}{l}\text { Insulin }+ \text { albumin }+ \\
\text { adrenaline }\end{array}$ \\
\hline
\end{tabular}

Experimental rate of fatty acid synthesis ( $\%$ of control rate) $610 * * *$ $406 * * *$ $138 * * *$ 124 171 81 $44 \dagger * *$

† Denton \& Randle (1967).
Experimental concn. (\% of control concn.)

$\begin{array}{ccc} & & \begin{array}{c}\text { Long-chain fatty } \\ \text { acyl-CoA }\end{array} \\ 131^{* * *} & 95 & 52^{* * *} \\ 53^{* * *} & 272^{* * *} & 110 \\ 320^{* * *} & 108 & 104 \\ & & \\ 279^{* * *} & 130^{*} & 77^{*} \\ 112 & 216^{* * *} & 110 \\ 82 & 263^{* * *} & 152^{* * *} \\ 104 & 313^{* * *} & 147^{* * *}\end{array}$

acyl-CoA may not have any inhibitory effect on acetyl-CoA carboxylase at physiological protein concentrations.

If citrate concentration were the sole controlling factor in fatty acid synthesis, then there should be parallel changes in rates of synthesis and citrate concentration. This was seen only in Expt. 4. In Expt. 1 and in the experiment with acetate, when fatty acid synthesis was increased, citrate concentration did not change. In Expts. 2, 3 and 5, citrate concentration increased without a corresponding change in synthesis rate, and in Expt. 6 the concentration of citrate was increased threefold whereas the rate of fatty acid synthesis was halved.

If the concentration of long-chain fatty acyl-CoA were the sole controlling factor in fatty acid synthesis, then there should be an inverse correlation between changes in its concentration and the fatty acid synthesis rate. This was seen in three experiments (Expts. 1, 3 and 6). However, in Expt. 4 and in the experiment with acetate, fatty acid synthesis was increased but there was no decrease in long-chain fatty acyl-CoA.

In summary, not one of the three factors studied (i.e. acetyl-CoA, citrate and long-chain fatty acylCoA) taken individually could be responsible for the control of fatty acid synthesis in these experiments. Moreover, when Expt. 5 and Expt. 6, in which there are similar changes in the concentrations of citrate, acetyl-CoA and long-chain fatty acyl-CoA, are compared, the rate of synthesis of fatty acid was halved in Expt. 6 but not significantly changed in Expt. 5. Therefore an additional or alternative factor seems to be involved in the control of fatty acid synthesis.
The authors are very grateful to Professor P. J. Randle for his encouragement and helpful advice and to $\operatorname{Dr} P$. B. Garland for many helpful discussions. Mrs I. M. Harris and Mrs P. Haslam are thanked for skilled technical assistance. The research was supported in part by grants from the British Diabetic Association, the Medical Research Council, the Royal Society and the British Insulin Manufacturers to Professor P. J. Randle. M.L.H. was a Travelling Fellow of the R. Samuel McLaughlin Foundation.

\section{REFERENCES}

Ball, E. G., Martin, D. B. \& Cooper, O. (1959). J.biol. Chem. 234, 774.

Bally, P. R., Cahill, G. F., jun., Leboeuf, B. \& Renold, A.E. (1960). J. biol. Chem. $235,333$.

Bortz, W. M. \& Lynen, F. (1963). Biochem. Z. 337, 505.

Bücher, Th., Czok, R., Lamprecht, W. \& Latzko, E. (1963). In Methods of Enzymatic Analysis, p. 253. Ed. by Bergmeyer, H. U. Berlin: Verlag Chemie.

Butler, F. E. (1961). Analyt. Chem. 33, 409.

Cahill, G. F., jun., Leboeuf, B. \& Flinn, R. B. (1960). J. biol. Chem. 235, 1246.

Carlson, L. A. (1963). J. Atheroscler. Res. 3, 334.

Chase, J. F. A. (1967). Biochem. J. 104, 503.

Chen, R. F. (1966). J. biol. Chem. $242,173$.

Crofford, O. B. \& Renold, A. E. (1965a). J. biol. Chem. 240, 14.

Crofford, O. B. \& Renold, A. E. (1965b). J. biol. Chem. 240, 3237.

Denton, R. M. \& Randle, P. J. (1966). Biochem. J. 100, 420.

Denton, R. M. \& Randle, P. J. (1967). Biochem. J. 104, 423.

Denton, R. M., Yorke, R. E. \& Randle, P.J. (1966). Biochem. J. 100, 407.

Dole, V. P. \& Meinertz, H. (1960). J. biol. Chem. 235, 2595. Duncombe, W. G. (1963). Biochem. J. 88, 7.

Fang, M. \& Lowenstein, J. M. (1967). Biochem. J. 105, 803. Flatt, J. P. \& Ball, E. G. (1964). J. biol. Chem. 239, 675. 
Flatt, J. P. \& Ball, E. G. (1966). J. biol. Chem. 241, 2862.

Garland, P. B., Newsholme, E. A. \& Randle, P. J. (1964). Biochem. J. 93, 665.

Garland, P. B. \& Randle, P. J. (1962). Nature, Lond., 196, 987.

Garland, P. B. \& Randle, P. J. (1964). Biochem. J. 98, 678.

Garland, P. B., Shepherd, D. \& Yates, D. W. (1965). Biochem. J. 97, 587.

Hohorst, H.-J. (1963a). In Methods of Enzymatic Analysis, p. 134. Ed. by Bergmeyer, H. U. Berlin: Verlag Chemie.

Hohorst, H.-J. (1963b). In Methods of Enzymatic Analysis, p. 215. Ed. by Bergmeyer, H. V. Berlin: Verlag Chemie.

Hohorst, H.-J. (1963c). In Methods of Enzymatic Analysis, p. 266. Ed. by Bergmeyer, H. U. Berlin: Verlag Chemie. Jungas, R. L. \& Ball, E. G. (1963). Biochemistry, $2,383$.

Krebs, H. A. \& Henseleit, K. (1932). Hoppe-Seyl. Z.210, 33.

Landau, B. R., Bartsch, G. E., Katz, J. \& Wood, H. G. (1964). J. biol. Chem. 239, 686.

Marquis, N. R. \& Fritz, I. B. (1964). J. Lipid Res. 5, 184.

Martin, D. B. \& Vagelos, P. R. (1962). J. biol. Chem. 237, 1787.

Moellering, H. \& Gruber, W. (1966). Analyt. Biochem. 17, 369.

Numa, S., Bortz, W. M. \& Lynen, F. (1965). In Advances in Enzyme Regulation, vol. 3, p. 407. Ed. by Weber, G. Oxford: Pergamon Press Ltd.

Pearson, D. J. (1965). Biochem. J. 95, 23c.

Pearson, D. J. \& Tubbs, P. K. (1967). Biochem. J. 105, 953.

Randle, P. J., Denton, R. M. \& England, P. J. (1968). Symp. biochem. Soc. 27, 87.
Rao, G. A. \& Johnston, J. M. (1967). Biochim. biophys. Acta, 144, 25.

Sanadi, D. R., Littlefield, J. W. \& Bock, R. M. (1952). J. biol. Chem. 197, 851.

Seubert, W. (1960). Biochem. Prep. 7, 80.

Short, D. J. \& Parkes, A. S. (1949). J. Hyg., Camb., 47, 209.

Simon, E. J. \& Shemin, D. (1953). J. Amer. chem. Soc. 75, 2520.

Slein, M. W. (1963). In Methods of Enzymatic Analysis, p. 117. Ed. by Bergmeyer, H. U. Berlin: Verlag Chemie.

Smith, S. W., Weiss, S. B. \& Kennedy, E. P. (1957). J. biol. Chem. 228, 915.

Steinberg, D., Vaughan, M. \& Margolis, S. (1961). J. biol. Chem. 236, 1631.

Synder, J. (1961). J. Lipid Res. 2, 195.

Trout, D. L., Estes, E. H., jun. \& Friedberg, S. J. (1960). J. Lipid Res. 1, 199.

Tubbs, P. K. \& Garland, P. B. (1964). Biochem. J. 93, 550.

Vagelos, P. R., Alberts, A. W. \& Martin, D. B. (1963). J. biol. Chem. 238, 533.

Vallance-Owen, J., Dennes, E. \& Campbell, P. N. (1958). Lancet, ii, 336.

Weiss, S. B. \& Kennedy, E. P. (1956). J. Amer. chem. Soc. 78, 3550.

Wieland, O. \& Weiss, L. (1963). Biochem. biophys. Res. Commun. 13, 26.

Winegrad, A. I. \& Renold, A. E. (1958). J. biol. Chem. 233, 267.

Wollenberger, A., Ristau, O. \& Schoffa, G. (1960). Pflüg. Arch. ges. Physiol. 270, 399. 